\title{
CONCEPT OF REVITALIZATION OF SELECTED MILITARY FACILITIES OF DRAGOONS BARRACKS IN OLSZTYN
}

\author{
Marek ZAGROBA ${ }^{1}$ \\ University of Warmia and Mazury in Olsztyn, \\ Faculty of Technical Sciences, Olsztyn, Poland
}

\begin{abstract}
Revitalization is a complex program to restore the functioning of the neglected urban areas in terms of spatial, economic and social. Revitalization activities on post-military facilities are stopping negative phenomena, such as degradation of space, social pathology or lack of proper functioning of the area, adapted to modern needs.

The object of the work is to present some aspects with the revitalization of former military facilities in the area of the Artyleryjska Street in Olsztyn. The presented design concept aims to revitalize a neglected area of the barracks, which will enable the activation site and include it in the city urban space. The method adopted in this work is the architectural project of adapting selected post-military facilities for new functions, affecting the economic development and social integration of people.
\end{abstract}

Keywords: revitalization, regeneration, architecture, urban planning, dragoon barracks

\section{INTRODUCTION}

Revitalization is a complex and generally long-term program to restore the functional capacity of neglected urban areas in terms of spatial, economic and social. Revitalization activities on former military facilities, often have the status of monuments, are the stopping of negative phenomena such as

\footnotetext{
${ }^{1}$ Corresponding author: University of Warmia and Mazury in Olsztyn, Faculty of Technical Sciences, Department of Building and Construction Physics, Heweliusz st 4 room 3.12, 10-719 Olsztyn, Poland, e-mail: mazag@uwm.edu.pl, tel.+48895234717
} 
marginalization and degradation of space, social pathology or lack of proper functioning of the area, adapted to modern needs.

The problem of revitalization in the Warmia-Mazury region relates primarily to cities downtown areas and post-military areas, and there are many of them. At the beginning of the last century, Olsztyn - the capital of the province, was called "Kasernepolis" or "city of barracks" [1]. This name resulted not only from the vast unit's barracks but also from the number of troops stationed in the city. A reminder of that time and the identity record of the region are extensive barracks compounds in the area of the Artyleryjska Street in Olsztyn, called the team Dragoons Barracks.

The subject of this paper is to present proposals for the revitalization of selected former military objects in the area of the Artyleryjska Street in Olsztyn. Presented design concept aims to revitalize a neglected area of barracks and to restore its former glory by giving the team a new, adapted to modern needs, character. As a result, area activation will be possible and including it in urban space. Historic adapting of barracks group for commercial purposes opens new prospects of development and provides the opportunity to create an attractive place not only for the city but also for the region.

The method adopted in this work is architectural and urban concept design of adaptation of selected former military objects for functions designed to bring certain economic benefits to the city and positively influence the social integration of citizens. The proposed new functions are connected with work thesis: revitalization of historical former military objects will increase the attractiveness of the city's image and contribute to the improvement of the economic, social and cultural situations.

\section{BRIEF HISTORICAL SUMMARY OF DRAGOONS BARRACKS}

At the end of the nineteenth century Olsztyn became a garrison town. The dominant buildings along the valley of the River Łyna were barracks buildings. The appearance of this part of the city has been shaped for the army (Fig. 1). The newly erected barracks teams, once on the outskirts of the city, were occupied, in turn, by cavalry formations, artillery and infantry. Each section was seated in a separate sector with facilities for training and recreation. It was an area away from the city, but included in its communication network [5]. Currently, buildings were absorbed by the sprawling city over the decades. In 1887 preparations began for construction of barracks groups. Two years later, construction was completed and on April 1, 1889 in the barracks was embedded 2nd Department of Westprussian Artillery Regiment No. 16 from 
Grudziądz. Completion of the first stage of construction was erecting officers' mess, which now houses a military kindergarten. Simultaneously with the construction of barracks buildings, there was work on regulation of the banks of the river. Nearby the barracks was built the iron bridge of St. Barbara (now made of reinforced concrete), for military purposes ${ }^{2}$. He combined artillery formations of buildings, located on the other side of Łyna, with complex of barracks and other military buildings (laundry facilities, food supplies).

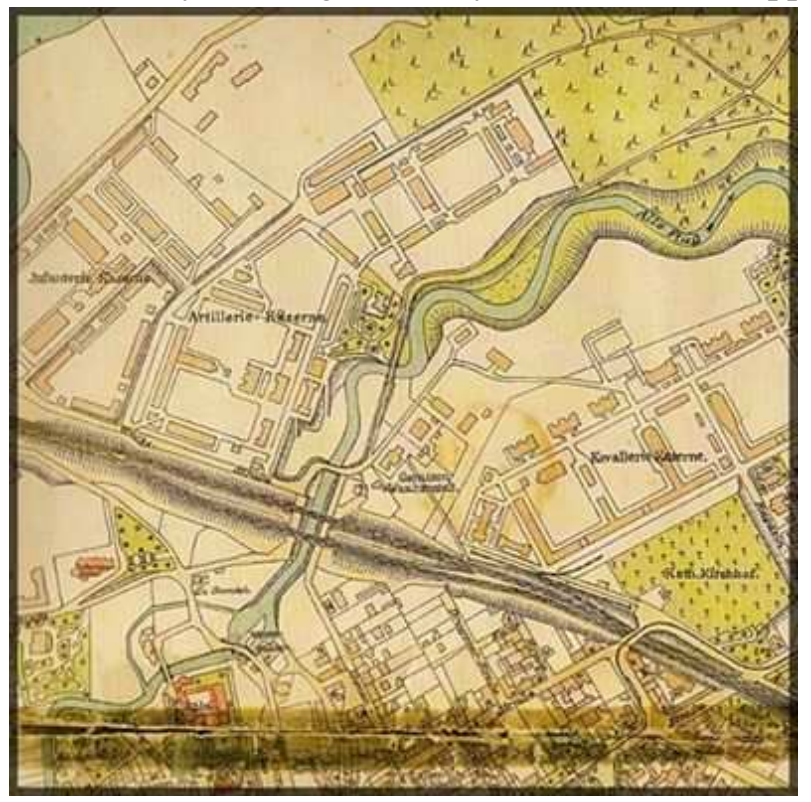

Fig. 1. The plan of Olsztyn in $1922^{3}$

In the years 1899-1902 in the north one erected second artillery barracks. Then one built stables and fire stations, apartment buildings, workshops and building staff. In 1901, extensive barracks were transferred to the newly formed 73rd Field Artillery Regiment, later called "Mazury". In 1902, works still continued on the expansion of the barracks, and in the construction of the new casino and residential building for families of soldiers.

Described buildings were arranged by ridge, around rectangular squares and are closed urban interiors (Fig. 2). Installation is maintained in the heavy neoromantic style appropriate for allocating objects [5]. Buildings were made of red brick, as objects of one, two or three floors. Its facade is adorned with brick

\footnotetext{
${ }^{2}$ The name of the bridge is derived from the name of the patron saint of artillerymen that was sacred Barbara.

${ }^{3}$ On the map are visible unit's artillery barracks on the western side of Łyna and cavalry on the east side of the river. Source: [2].
} 
architectural detail in the form of friezes (glazed brick), cornices imitating consoles and ornamental bands in window and door joinery.

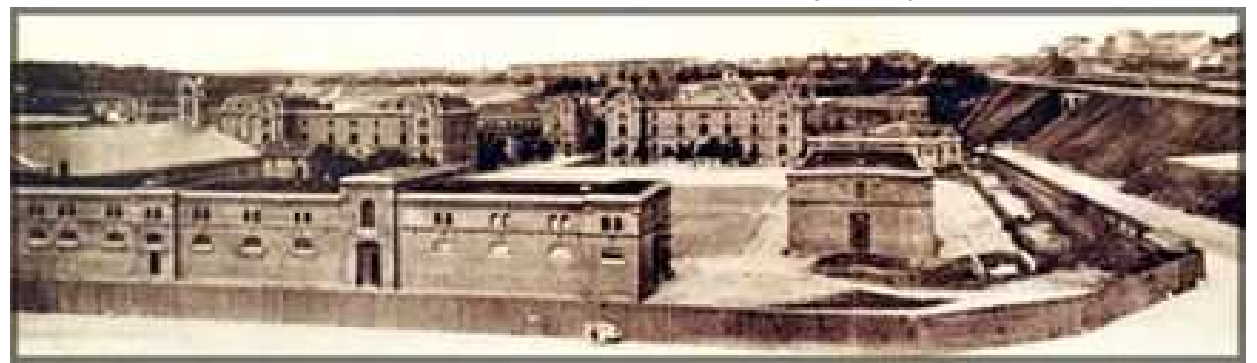

Fig. 2. View of the barracks from the region of the West Railway Station (about 1900). Source: [2]

In 1898 near Długie Lake, one built central part of a final three-part barracks unit, designed for 150 Infantry Regiment, which came to Olsztyn from Kostrzyn and Frankfurt. The last part of the complex was built in years 1910-1911. Its members became Gunsmith Workshop and garages to use for the machine gun company. The whole military complex was arranged around three squares. Brick barracks for the most part were erected on the plan of the letter "E" and their roofs are generally gable or mansard [5]. The large scale of the whole urban and architectural layout may indicate that the complex of 26 buildings covers an area of 11 hectares and the length of the longest object (southern stable) exceeds 200 metres.

After 1945, the whole barracks complex was used for military purposes, becoming the property of State Treasury. Today, many of the objects were sold to private owners. Due to the year of construction of the complex and its specific architectural, landscape and cultural qualities, in 2009 historical buildings was subject to a conservation area and entered in the monuments register. Owing to which, historic barracks in Olsztyn become one of the most protected monuments in the city.

Rules to protect the complex relate to the spatial arrangement of buildings, squares and streets layout, lay of the land, elements of green, historic roads, small architecture objects (stairs, retaining walls, etc.) and the viewing corridors. Any repair works on the historic building on protected area may be carried out only with the consent of the provincial monument conservator and under their supervision. It is very important, during works related to the restoration of historic buildings, to maintain their status to a degree as close as possible to the original. This applies to construction height, body shaping buildings, the shape of the roof, architectural details of the facade, historic woodwork and preserved furnishings. In the case of the introduction of the new 
building, one must adapt it to the historical layout of the whole unit. An important assumption in the context of spatial order is the elimination of secondary objects within the protection zone.

\section{THE CONCEPT OF REVITALIZATION OF SELECTED OBJECTS}

Building barracks unit is a place with distinct spatial qualities, requiring a "stimulating life". The key to this is their adaptation to new functions, serving residents of Olsztyn. Therefore, it is important to adjust the value in use of barracks unit to contemporary needs by giving objects commercial functions, while maintaining their cultural and historical values. An example of such positive action can serve an adaptation project of three buildings to new attractive features. Two of them functioned as stables and one as a riding school.

The building of the former stables (building "B") was, in the project, adapted for educational purposes, as well as office and commercial-service needs (Fig. 3). One separated there two functional parts, whose border is a former riding school, adjacent to the object. One part of the object was devoted to modern, two-level language school, made up of small, well-equipped and computerized classrooms. In this part of the building was also located a place favouring education of the youngest residents of the city.

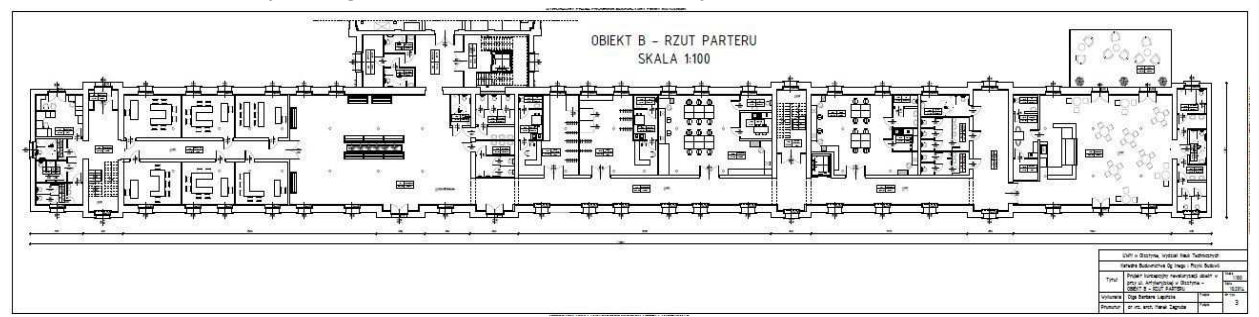

Fig. 3. The adaptation plan of the barracks building. Source: [4]

In the rest of the building, on two floors were designed offices and service premises, as well as workshops. All units have separate entrances, thanks to the circulation area, flowing along the building. The project also provided the availability of all facilities for the disabled.

The second building undergoing adaptation formerly also functioned as stable (Fig. 4). The project involves the restaurant in it, as well as services and a fitness centre. A large area was designed for training rooms - the main room with exercise equipment and fitness room for women with a separate entrance. 


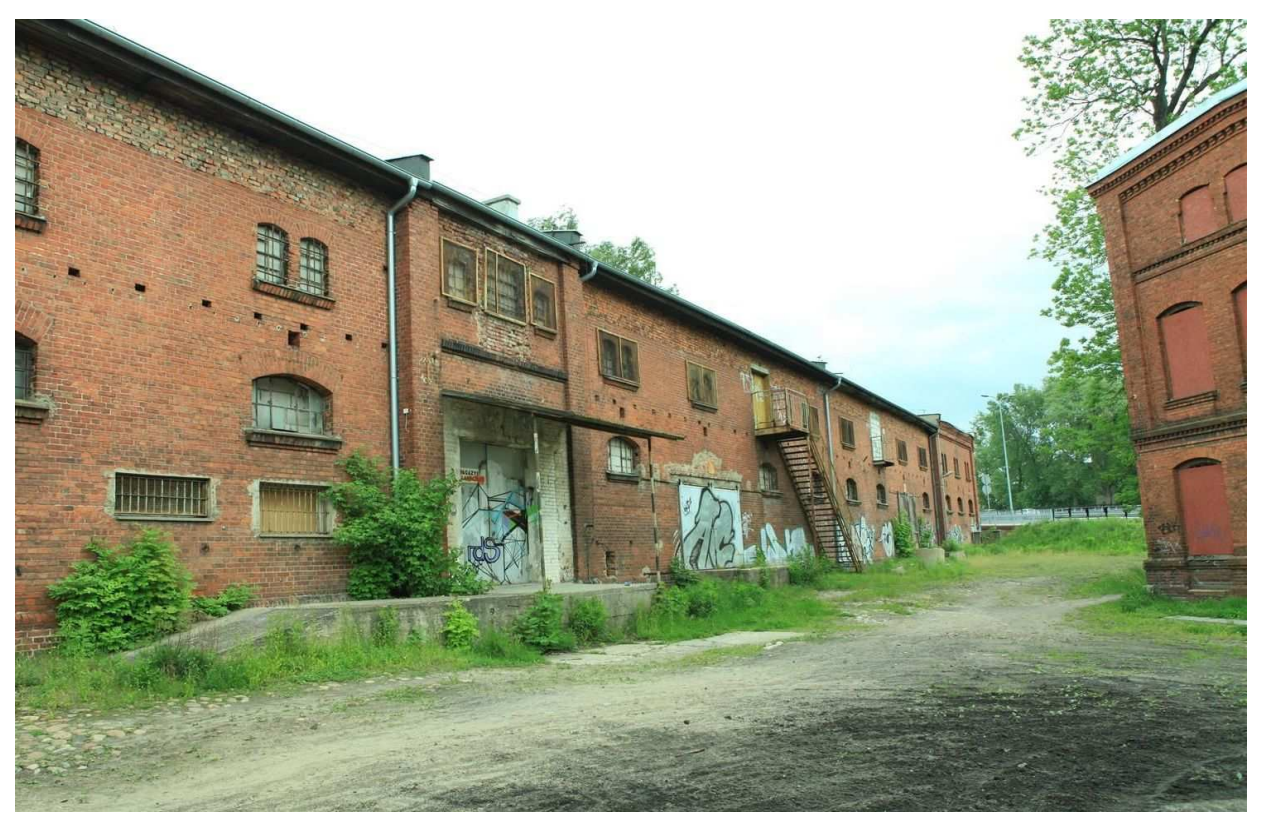

Fig. 4. Building of the southern stable. Photo: author

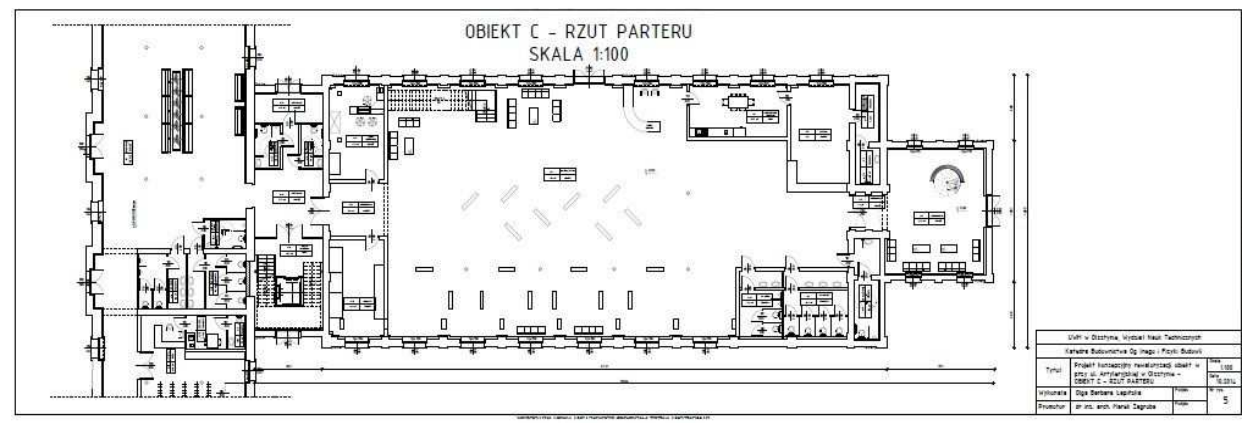

Fig. 5. Adaptation plan of the barracks. Source: [4]

Former horse riding (object " $\mathrm{C}$ ") is a building that has been converted, in a design, to an art gallery (Fig. 5). A large area of the building will allow for a diverse arrangement of exhibition space - fixed and variable exposition for individual or group exhibitions. Because of its size, the building can also be a place of artistic events, meetings with authors or promotion of artists. In addition, project of this facility provides building entresol. In this way one separated space that could be used for holding arts and crafts workshops for children and youth.

Implementation of the presented project designs requires little transformation of the objects interior. They are limited to making a few ceiling joists and partition 
walls. The facades of buildings assumed the removal of secondary plaster, defects and cracks and one also cleaned up the rhythm composition of the window and door openings.

\section{CONCLUSIONS}

The Unit of Dragoons Barracks in Olsztyn, despite the large spatial, architectural and cultural values, is now a much neglected complex. The revitalization of this area, having great potential, is an opportunity to increase the attractiveness of the barracks and thereby enriching the city's image. Proper design solutions, preceded by a series of analyzes can yield fruitful results, so that the area of barracks become a living and valuable district of Olsztyn.

Presented design solutions reason the work thesis. They also allow the following conclusions:

- restoration of the barracks complex will enhance the attractiveness of urban space (positive spatial solutions),

- well-planned revitalization activities as an example of the connection of modern solutions with the historic character of historic buildings, will positively influence the behaviour of unit identity,

- construction of revitalization programs is an opportunity for new prospects of functioning and development of the degraded area of Dragoons Barracks,

- implementation of revitalization programs is determined by positive changes in space and contributes to the socio-economic and cultural development (office, commercial, educational, cultural and recreational functions).

\section{REFERENCES}

1. Bętkowski R.: Dragoni z Olsztyna. Dzieje formacji i koszar, Olsztyn, Imago Mundi 2011, 5.

2. Bętkowski R.: Olsztyn jakiego nie znacie, Olsztyn, Imago Mundi 2003.

3. Lokalny Program Rewitalizacji Obszaru Miasta Olsztyn na lata 2007-2015. Dziatanie 4.3. Restrukturyzacja terenów powojskowych i poprzemystowych, Olsztyn 2010, 76.

4. Rewitalizacja obiektów powojskowych $w$ rejonie ul. Artyleryjskiej w Olsztynie, praca dyplomowa inżynierska,wyk. przez Olgę Barbarę Łapińską pod kier. Marka Zagroby, UWM Olsztyn 2014, mat. niepubl.

5. Rzempołuch A.: Architektura i urbanistyka Olsztyna 1353-1953. Od założenia miasta po odbudowe zniszczeń wojennych, Olsztyn, Remix 2004, 61, 77, 93. 


\section{KONCEPCJA REWITALIZACJI WYBRANYCH OBIEKTÓW POWOJSKOWYCH ZESPOŁU KOSZAR DRAGONÓW W OLSZTYNIE}

\section{Streszczenie}

Rewitalizacja jest złożonym programem przywrócenia zdolności funkcjonowania zaniedbanych obszarów zurbanizowanych pod kątem przestrzennym, gospodarczym i społecznym. Działania rewitalizacyjne dotyczące obiektów powojskowych, stanowią zatrzymanie negatywnych zjawisk, takich jak marginalizacja i degradacja przestrzeni, patologia społeczna czy też brak odpowiedniego funkcjonowania obszaru, dostosowanego do współczesnych potrzeb.

Pod koniec XIX wieku, Olsztyn zyskał przydomek "Kasernepolis" czyli "miasto koszar". Koszary Dragonów to najstarszy zachowany kompleks architektoniczny miasta, który w 2009 r. został wpisany do rejestru zabytków i objęty jest programem rewitalizacji.

Przedmiotem pracy jest przedstawienie wybranych aspektów i wymiana doświadczeń z zakresu rewitalizacji obiektów powojskowych w rejonie ulicy Artyleryjskiej w Olsztynie. Zaprezentowana koncepcja projektowa ma na celu ożywienie zaniedbanego obszaru koszar, dzięki czemu możliwa będzie aktywizacja terenu i włączenie go w przestrzeń miejską. Adaptacja zabytkowego kompleksu na cele komercyjne otwiera nowe perspektywy rozwoju oraz daje możliwość stworzenia miejsca atrakcyjnego nie tylko dla miasta ale i regionu. Metodą przyjętą w pracy jest projekt architektoniczny adaptacji wybranych obiektów powojskowych na nowe funkcje, wpływające na rozwój gospodarczy a także integrację społeczną mieszkańców.

Słowa kluczowe: rewitalizacja, rewaloryzacja, architektura, urbanistyka, koszary dragonów

Editor received the manuscript: $24.04 .2015 r$. 